\title{
Zarządzanie relacjami uczelni publicznych z przedsiębiorstwami
}

\author{
Dr Magdalena Ławicka iD \\ Uniwersytet Szczeciński \\ Wydział Ekonomii Finansów i Zarządzania \\ Katedra Organizacji i Zarządzania
}

\section{Wprowadzenie}

Problematyka oceniania relacji, które nawiązuje i rozwija uczelnia ze swoimi interesariuszami, stanowi istotny aspekt wpływający na dalszy rozwój szkół wyższych oraz instytucji w otoczeniu. Podjęty w rozdziale temat obejmuje identyfikację potrzeb uczelni i otoczenia, określenie celów oraz wyboru partnera do wspólnego funkcjonowania. Jest to więc szereg działań i procesów, które warunkują osiąganie wyznaczonych korzyści w dłuższym czasie.

Przeprowadzone przez autorkę rozdziału badania pozwoliły na scharakteryzowanie obszarów współpracy pomiędzy uczelniami a przedsiębiorstwami, a także na sformułowanie propozycji działań w zakresie zarządzania relacjami, czego fundamentem powinna być staranna analiza realizowanych projektów.

W opracowaniu ukazano wyniki badań, które przeprowadzono za pomocą takich metod badawczych jak krytyczna analiza literatury przedmiotu oraz metoda sondażu diagnostycznego (kwestionariuszowa). W trakcie przeprowadzonych czynności badawczych autorka starała się znaleźć odpowiedzi na następujące pytania:

- „Jakie są obszary współpracy prowadzonej przez uczelnie z przedsiębiorstwami?";

- „Które z działań są najczęściej podejmowane we współpracy z przedsiębiorstwami?";

- „Czy na badanych uczelniach jest prowadzona sformalizowana ocena współpracy, dająca możliwość generowania oficjalnej informacji zwrotnej dotyczącej prowadzonych wspólnie działań?”.

Podmiot rozważań i badań stanowiły wydziały ekonomiczne publicznych uczelni w województwie zachodniopomorskim. 


\section{Wyzwania, przed którymi stoi uczelnia w XXI wieku}

Jednym z najważniejszych aktów prawnych regulujących zakres i sposób funkcjonowania uczelni, zarówno publicznych, jak i niepublicznych, jest Ustawa z dnia 20 lipca 2018 r. - Prawo o szkolnictwie wyższym i nauce (UPSWiN). Weszła ona w życie 1 października 2018 roku. Zarówno w samej ustawie, jak i innych aktach prawnych dotyczących szkolnictwa wyższego można znaleźć wiele odniesień do współpracy uczelni z otoczeniem społeczno-gospodarczym. Misją systemu szkolnictwa wyższego i nauki jest prowadzenie najwyższej jakości kształcenia oraz działalności naukowej, kształtowanie postaw obywatelskich, a także uczestnictwo $\mathrm{w}$ rozwoju społecznym oraz tworzeniu gospodarki opartej na innowacjach ${ }^{1}$.

Zgodnie z zapisami UPSWiN podstawowymi zadaniami uczelni są między innymi²:

- prowadzenie kształcenia;

- prowadzenie działalności naukowej, świadczenie usług badawczych oraz transfer wiedzy i technologii do gospodarki;

- kształcenie i promowanie kadr uczelni;

- działania na rzecz społeczności lokalnych i regionalnych.

Ośrodki naukowe, w tym uczelnie, mają ogromny wpływ na osiąganie narodowych celów społecznych i gospodarczych oraz na budowę kapitału intelektualnego i społecznego kraju. Szkolnictwo wyższe realizuje dwie główne funkcje: kształcenie oraz prowadzenie badań naukowych, wpływając istotnie na postawy jednostek i całego społeczeństwa ${ }^{3}$. Obecnie obowiązujące akty prawne dotyczące szkolnictwa wyższego i nauki regulują zasady transferu wiedzy i technologii z uczelni do gospodarki. Jednak w zakresie współpracy szkolnictwa wyższego z otoczeniem społeczno-gospodarczym UPSWiN nie wskazuje stosowania żadnych metod oceny skuteczności takiej współpracy.

Uczelnie oddziałują na całe społeczeństwo poprzez postawy studentów oraz transfer wiedzy. Kształtują elity, uczestniczą w procesie budowania społeczeństwa opartego na wiedzy i wpływają na otaczającą rzeczywistość ${ }^{4}$. Odgrywają więc ogromną rolę w rozwoju społeczno-gospodarczym.

1 Art. 2 Ustawy z dnia 20 lipca 2018 r. - Prawo o szkolnictwie wyższym i nauce (Dz.U. z 2018 r., poz. 1668).

2 Art. 11.1 UPSWiN.

3 Por. Misja, wizja i cele strategiczne szkolnictwa wyższego w Polsce w perspektywie 2020 roku, Ernst \& Young Business Advisory i Instytut Badań nad Gospodarką Rynkową, listopad 2009, s. 3, https://docplayer.pl/16287467-Misja-wizja-i-cele-strategiczne-szkolnictwa-wyzszego-w-polsce-w-perspektywie-2020-roku-listopad-2009.html (dostęp: 20.12.2019).

4 Por. M. Geryk, Społeczna odpowiedzialność uczelni w percepcji jej interesariuszy. Raport z badań, Oficyna Wydawnicza SGH - Szkoła Główna Handlowa w Warszawie, Warszawa 2010, s. 9. 
Gwałtowny wzrost znaczenia wiedzy w globalnym świecie spowodował, że stała się ona podstawową wartością w rozwoju społeczno-gospodarczym kraju. Zmiany postaw społecznych wpływają na to, że coraz większa liczba osób - nabywców usług edukacyjnych - korzysta z usług na różnym etapie rozwoju i staje się coraz bardziej wymagająca wobec podmiotów, które je świadczą5.

Nawiązując do teorii interesariuszy w ujęciu publicznej szkoły wyższej, należy zastanowić się, komu służy uczelnia i w jakim otoczeniu funkcjonuje, a także czy jej działania są zgodne z ich oczekiwaniami ${ }^{6}$. Do najczęściej wymienianych w literaturze interesariuszy uczelni należą: studenci i ich rodzice, przedstawiciele władz (lokalnych, krajowych), pracownicy uczelni, inne instytucje edukacyjne, przedsiębiorstwa i inne organizacje lokalne, regionalne bądź krajowe. Identyfikacja wszystkich interesariuszy nie jest łatwym zadaniem, gdyż obejmuje szerokie grono osób i podmiotów, które bezpośrednio lub pośrednio wpływają na instytucje edukacyjne. Istotne jest jednak to, że każdy z interesariuszy szkoły wyższej ma swoje oczekiwania wobec uczelni. Potrzeby każdego z nich powinny być rozpatrywane na drodze dbania o jakość oferty edukacyjnej7. Potencjalne wymagania i oczekiwania wybranych grup odbiorców wobec publicznej uczelni zostały przedstawione w tabeli 1 .

Przedstawione w tabeli 1 roszczenia i oczekiwania komunikowane uczelni przez interesariuszy dotyczą głównie przydatności wiedzy dostarczanej przez uczelnie na rynek. Usługi świadczone na poziomie wyższym nie mogą więc być postrzegane jedynie jako oferta kształceniowa, ale muszą być wspierane rozwojem badań i innowacji na uczelniach dysponujących bogatym kapitałem intelektualnym. W tym kontekście warto zwrócić uwagę na złożoność obecnych relacji uczelni z otoczeniem, nie tylko w obszarze kształcenia, badań oraz rozwoju innowacji, ale również z perspektywy skutecznego zarządzania współczesną szkołą wyższą ${ }^{8}$.

Uczelnie, jako podmioty, których rolą jest aktywny wpływ na kształt gospodarki, za główny cel powinny obrać wzmocnienie współpracy z pracodawcami. Kierunki i sposoby kształcenia powinny powstawać na drodze konsultacji, tak

5 Tamże, s. 39-40.

6 Pojęcie interesariuszy po raz pierwszy pojawiło się w memorandum Instytutu Badawczego Stanford (Stanford Research Institute) w 1963 roku. Zostało zdefiniowane jako "grupy, bez których wsparcia organizacja przestałaby istnieć" - R.E. Freeman, Strategic Management. A stakeholder approach, Cambridge University Press, Cambridge 2010, s. 31.

7 Por. J. Bakonyi, Kapitat intelektualny uczelni a jakość kształcenia, [w:] M. Jabłoński (red.), „Zarządzanie. Zeszyty Naukowe Wyższej Szkoły Humanitas”, Oficyna Wydawnicza Humanitas, Sosnowiec 2009, s. 40.

8 Por. M. Pluta-Olearnik, Przedsiębiorcza uczelnia i jej relacje z otoczeniem, Wydawnictwo Difin, Wroctaw 2009, s. 11. 
aby pracodawcy mogli swobodnie komunikować uczelniom swoje potrzeby w zakresie kształtowania kluczowych kompetencji wśród studentów - przyszłych pracowników.

Tabela 1. Oczekiwania wybranych interesariuszy wobec publicznej uczelni

\begin{tabular}{|c|c|}
\hline Interesariusz & Przykładowe oczekiwania interesariusza \\
\hline Student & $\begin{array}{l}\text { - Przydatność wiedzy dla rozwoju zawodowego i ogólnego } \\
\text { - Zapewnienie konkurencyjności na rynku pracy } \\
\text { - Kształcenie potrzebnych specjalistów } \\
\text { - Wspieranie praktyk zawodowych studentów } \\
\text { - Kompleksowość wiedzy }\end{array}$ \\
\hline $\begin{array}{l}\text { Rodzice } \\
\text { studenta }\end{array}$ & $\begin{array}{l}\text { - Prestiż uczelni, do której posyłają swoje dziecko } \\
\text { - Przydatność wiedzy dla sukcesu zawodowego studenta } \\
\text { - Pozycja uczelni w rankingu uczelni }\end{array}$ \\
\hline Absolwent & $\begin{array}{l}\text { - Posiadanie wiedzy uniwersalnej, którą bez problemu będzie można } \\
\text { wykorzystać na rynku pracy } \\
\text { - Praktyczne możliwości wykorzystania wiedzy i umiejętności przekazanych } \\
\text { podczas studiów }\end{array}$ \\
\hline Rynek pracy & $\begin{array}{l}\text { - Absolwenci mający niezbędną wiedzę teoretyczną i umiejętności praktyczne } \\
\text { - Studenci mający umiejętność wykorzystania wiedzy teoretycznej w praktyce } \\
\text { - Elastyczność pracowników (absolwentów), rozumiana jako umiejętność } \\
\text { dostosowywania się do zmiennej sytuacji w przedsiębiorstwach } \\
\text { - Otwartość szkoły wyższej na współpracę w zakresie prowadzenia badań } \\
\text { i analiz służących rozwojowi organizacji działających na rynku pracy }\end{array}$ \\
\hline
\end{tabular}

Źródło: opracowanie własne na podstawie M. Ławicka, Różnorodność oferty edukacyjnej publicznych uczelni w Polsce, „Przedsiębiorczość i Zarządzanie” 2017, t. XVIII, z. 11, cz. 2, s. 158; J. Bakonyi, Kapitat intelektualny uczelni a jakość kształcenia, [w:] M. Jabłoński (red.), „Zarządzanie. Zeszyty Naukowe Wyższej Szkoły Humanitas”, Oficyna Wydawnicza Humanitas, Sosnowiec 2009, s. 41; M. Geryk, Społeczna odpowiedzialność uczelni w percepcji jej interesariuszy. Raport z badań, Oficyna Wydawnicza SGH - Szkoła Główna Handlowa w Warszawie, Warszawa 2010, s. 48-54.

\section{Zarządzanie relacjami z przedsiębiorstwami jako jednymi z najważniejszych interesariuszy publicznej uczelni}

Uczelnie powinny intensywniej kierować orientację w kierunku nabywców swoich usług, a więc studentów oraz pracodawców - przedstawicieli rynku pracy. Powinny budować i wzmacniać relacje z otoczeniem biznesowym, tak by dłużej nie oddzielać swojej istoty społecznej i naukowej od biznesowej9.

9 A. Drapińska, Zarządzanie relacjami na rynku usług edukacyjnych szkół wyższych, Wydawnictwo Naukowe PWN, Warszawa 2012, s. 83. 
Wprowadzenie Polskiej Ramy Kwalifikacji (PRK) jako układu odniesienia dla kwalifikacji nadawanych w Polsce dało każdej uczelni możliwość kształtowania własnego programu na podstawie efektów kształcenia, a jednostki prowadzące poszczególne kierunki zostały zobowiązane dostosować je do nowych wymogów ${ }^{10}$. Podejście oparte na efektach kształcenia wymaga silnych powiązań uczelni z praktyką gospodarczą w kontekście konkretnych, dotyczących kształcenia absolwentów oczekiwań firm i organizacji.

Wyzwaniem jest umiejętne planowanie treści zawartych w programach studiów, w sposób spełniający wymogi współczesnego rynku pracy, do czego niezbędne jest nawiązanie trwałych relacji uczelni z otoczeniem gospodarczym ${ }^{11}$.

Na rynku usług edukacyjnych szkół wyższych wyróżnia się wiele różnych rodzajów relacji. Samo pojęcie relacja ma swoje korzenie w języku łacińskim - relatio ('odniesienie, kontakt, wzgląd, stosunek')12. Powszechnie używane słowo relacja oddaje zależności występujące między podmiotami na poziomie głębszym niż zewnętrzny, powierzchowny kontakt, dotycząc najczęściej wzajemnego oddziaływania stron.

Usługa edukacyjna jest procesem, a nie jednorazowym aktem, trwa w czasie i zazwyczaj wymaga nawiązania relacji (na przykład pomiędzy wykładowcą a studentem) w trakcie jej świadczenia. W przypadku szkolnictwa wyższego interakcje zachodzące pomiędzy partnerami zostały określone w literaturze mianem wymiany społecznej, z uwagi na to, że osiągane korzyści mają zarówno wymiar ekonomiczny, jak i społeczny ${ }^{13}$.

Rogoziński przedstawia pewien zestaw wytycznych, pomocnych przy budowie i rozwoju relacji pomiędzy usługodawcą a usługobiorcą. Podkreśla między innymi: znaczenie pierwszego kontaktu, testowanie woli i gotowości wchodzenia w relacje, weryfikację opłacalności dalszego podtrzymywania relacji. Zwraca uwagę na to, że sukces każdej organizacji zależy od dobrego zarządzania relacjami, a więc od tego, jak buduje i świadomie rozwija ona relacje ze swoimi usługobiorcami ${ }^{14}$.

10 W PRK jest osiem poziomów. Każdy jest opisywany za pomocą ogólnych charakterystyk zakresu i stopnia skomplikowania wiedzy, umiejętności i kompetencji społecznych, wymaganych od osób mających kwalifikacje danego poziomu.

11 K. Koj, Relacje z otoczeniem gospodarczym jako element ksztattowania programu ksztatcenia. Doświadczenia z Programu Partnerstwa Biznesowego w Wydziale Zamiejscowym w Chorzowie WSB w Poznaniu, [w:] J. Dworak, J. Jaworski, Zarzq̨dzanie szkołq wyższq̨: dylematy i wyzwania, t. 14, CeDeWu, Warszawa 2011, s. 82.

12 Słownik języka polskiego PWN, www.sjp.pwn.pl (dostęp: 28.12.2019).

13 Por. A. Drapińska, Zarzqdzanie relacjami..., s. 86.

14 Por. K. Rogoziński, Zarządzanie relacjami w usługach, Wydawnictwo Difin, Warszawa 2006, S. 22. 
Zarządzanie relacjami przez szkołę wyższą jest ciągłym i długotrwałym procesem kreowania relacji szkoły wyższej z jej partnerami w otoczeniu (studentami, przedsiębiorstwami, władzami, sponsorami itp.) przez wspólne tworzenie wartości w taki sposób, aby cele wszystkich stron zostały zrealizowane ${ }^{15}$. Helgesen twierdzi, że uczelnia nie powinna w swoich działaniach koncentrować się tylko na usłudze edukacyjnej. Podejmowane działania powinny być rozpatrywane szerzej, z uwagi na potrzebę kształtowania takich zasobów jak ludzie, technologia, know-how, czas oraz odpowiedni system kierowania tymi zasobami podczas trwania relacji, tak aby tworzyć satysfakcjonującą ofertę ${ }^{16}$.

Działania podejmowane $\mathrm{w}$ ramach zarządzaniami relacjami powinny być starannie przemyślane, zaplanowane i zorganizowane. Powinny wynikać z długoterminowej, systematycznie wprowadzanej i realizowanej strategii. Powinny zostać rozpoznane i zintegrowane zasoby oraz działania uczelni niezbędne do zarządzania relacjami. Uczelnia potrzebuje do tego celu wielu informacji, które powinny być systematycznie zbierane i analizowane ${ }^{17}$.

Kreując wartość usługi, trzeba pamiętać, że - chcąc osiągnąć sukces na rynku - należy zapewnić nabywcy usługi obsługę na najwyższym poziomie. Można to w obecnej dobie osiągnąć jedynie dzięki dogłębnej wiedzy o oczekiwaniach nabywców ${ }^{18}$.

Jedną z koncepcji ważnych dla zrozumienia istoty relacji pomiędzy podmiotami jest teoria wymiany społecznej autorstwa amerykańskiego socjologa Homansa. Zgodnie z nią relacje między stronami są nawiązywane zarówno z uwagi na wartość ekonomiczną, jak i społeczną. Zachowanie społeczne to wymiana dóbr materialnych, ale również niematerialnych, takich jak symbole uznania i prestiżu ${ }^{19}$.

Relacje oznaczają więc nie tylko wspólne osiąganie korzyści wynikających wprost $\mathrm{z}$ realizacji postawionego celu, ale i dotyczą kwestii wspierających, takich jak zaufanie czy zaangażowanie partnerów. Wtedy może pojawić się wartość dodana, na przykład w postaci rozwoju kompetencji - w wyniku transferu wiedzy pomiędzy partnerami. Mogą również powstać inne wartości, które nie pojawiły się na etapie planowania współpracy. Odpowiednie zaplanowanie działań oraz dbałość o jakość relacji wpływają na satysfakcję i zaufanie, cementujące współpracę i dające możliwość kolejnych wspólnych projektów przy aktywnym zaangażowaniu i chęci obu stron.

15 Por. A. Drapińska, Zarzq̨dzanie relacjami..., s. 145.

16 O. Helgesen, Marketing for Higher Education: A Relationship Marketing Approach, „Journal of Marketing for Higher Education" 2008, vol. 18(1), s. 53.

17 Tamże.

18 J. Ławicki, Marketing sukcesu - partnering, Wydawnictwo Difin, Warszawa 2005, s. 177.

19 G.C. Homans, Social Behaviour as Exchange, „American Journal of Sociology” 1958, vol. 63, no. 6, s. 606 . 
Relacje szkół wyższych z przedsiębiorstwami mogą przybierać różną postać. Mogą to być relacje z przedsiębiorstwami jako ${ }^{20}$ :

- klientami różnego rodzaju usług badawczych (badania, ekspertyzy itp.);

- sponsorami;

- klientami usług edukacyjnych (szkolenia, kursy, warsztaty, studia podyplomowe dla pracowników przedsiębiorstw);

- oferentami praktyk i staży dla studentów;

- wykładowcami na uczelni (relacje z pracownikami przedsiębiorstw);

- pracodawcami dla absolwentów.

Niezwykle istotne jest to, co dana uczelnia oferuje i czy spełnia tym oczekiwania i potrzeby swoich interesariuszy. Wartość oferowana we współpracy uważana jest za jeden z najważniejszych elementów warunkujących budowanie pozytywnych relacji na rynku. Uczelnie powinny dbać o generowanie jak największej wartości w odniesieniu do swojej oferty edukacyjno-badawczej, co powinno być wynikiem właściwego zarządzania relacjami ze swoimi interesariuszami.

Warto jednak podkreślić, że w zakresie postrzegania wartości przez klientów zaszły duże zmiany. Podejście mówiące, że to organizacja tworzy wartość niezależnie od nabywców, to już relikt przeszłości. Nabywca usług XXI wieku przekształcił się z odizolowanego we współdziałającego z innymi, z nieświadomego $\mathrm{w}$ poinformowanego, $\mathrm{z}$ biernego $\mathrm{w}$ czynnego ${ }^{21}$. Przedsiębiorstwa, które podejmują współpracę z uczelnią, coraz częściej dążą do bycia równoprawnym partnerem, chcą aktywnie uczestniczyć w dialogu na temat propozycji usług oferowanych przez uczelnie. Na rynku coraz częściej widać rozwój procesów współtworzenia wartości, a miejscem, w którym tworzy się wartość, jest interakcja pomiędzy nabywcą a organizacją.

Relacje pomiędzy nabywcami a organizacjami dają możliwość współtworzenia wartości. Skoro coraz większa liczba osób poszukuje rozmaitych interakcji, proces tworzenia wartości będzie obejmować rozmaite doświadczenia współtworzenia. Kontekst i angażowanie się nabywcy przyczyniają się do konkretnego doświadczenia dla danej osoby i wyjątkowości współtworzonej wartości. Rynek zaczyna przypominać forum, zorganizowane wokół indywidualnych osób i ich doświadczeń współtworzenia, a nie wokół biernych stref popytu na ofertę danej organizacji ${ }^{22}$.

W przypadku usług edukacyjnych oraz badawczych, świadczonych przez uczelnie, tworzenie wartości z klientem (nabywcą tych usług) powinno odnosić się do badania oczekiwań i potrzeb interesariuszy (m.in. studentów i przedsiębiorstw),

20 A. Drapińska, Zarzq̨dzanie relacjami..., s. 127.

21 C.K. Prahalad, V. Ramaswamy, Przysztość konkurencji. Wspóttworzenie wyjq̨tkowej wartości wraz z klientem, Polskie Wydawnictwo Ekonomiczne, Warszawa 2005, s. 14.

22 Tamże, s. 24-25. 
a następnie projektowania odpowiedniej oferty edukacyjnej i badawczej oraz angażowania stron do rozwoju, poprzez aktywny udział w edukacji i badaniach. Oferowana wartość powinna być oparta na długofalowym interesie interesariuszy w społeczeństwie, które jako całość ma czerpać korzyści z systemu edukacji (misja szkolnictwa wyższego $)^{23}$.

Uczelnie, aby zdobyć i utrzymać interesariusza, który znajduje się w profilu ich zainteresowań, muszą zaproponować mu ekstrawartość, a przede wszystkim pełne partnerstwo. W związku z tym wydaje się, że pilnym wymogiem na konkurencyjnym rynku edukacyjnym powinno stać się stałe uczestnictwo przedstawicieli praktyki gospodarczej w posiedzeniach gremiów naukowych na uczelniach. Aby relacje nauki z biznesem przynosiły profity i wzajemną satysfakcję, powinny być koherentne, gdyż tylko wtedy możliwa będzie pełna, twórcza interakcja.

\section{Charakterystyka relacji uczelni z przedsiębiorstwami - przyktad województwa zachodniopomorskiego}

Na potrzeby niniejszego rozdziału przeprowadzono badanie wśród kadry zarządzającej podstawowymi jednostkami organizacyjnymi na uczelniach publicznych w województwie zachodniopomorskim. Badaniu podlegały wszystkie wydziały ekonomiczne o profilu ogólnoakademickim publicznych uczelni. Na potrzeby prac badawczych wybrano wydziały ekonomiczne jako jednostki, których profil działalności jest ściśle związany z kształtowaniem sposobów funkcjonowania przedsiębiorstw w gospodarce.

Badanie zostało przeprowadzone za pomocą metody sondażu diagnostycznego przy użyciu skomputeryzowanego wywiadu internetowego CAWI (Computer Assisted Web Interviewing) w okresie kwiecień - lipiec 2017 roku.

Celem przeprowadzonych badań była charakterystyka współpracy uczelni z przedsiębiorstwami - zarówno w zakresie obszarów prowadzonej współpracy i jej częstotliwości, jak i analizy doświadczeń ze zrealizowanych projektów.

Wyniki przeprowadzonych badań wykazały, że aż 89\% ankietowanych podjęło do tej pory współpracę z przedsiębiorstwami. Rysunek 1 wskazuje odpowiedzi respondentów na pytanie o wielokrotne podejmowanie współpracy z przedsiębiorstwami.

23 Por. A. Drapińska, Zarzq̨dzanie relacjami..., s. 188. 


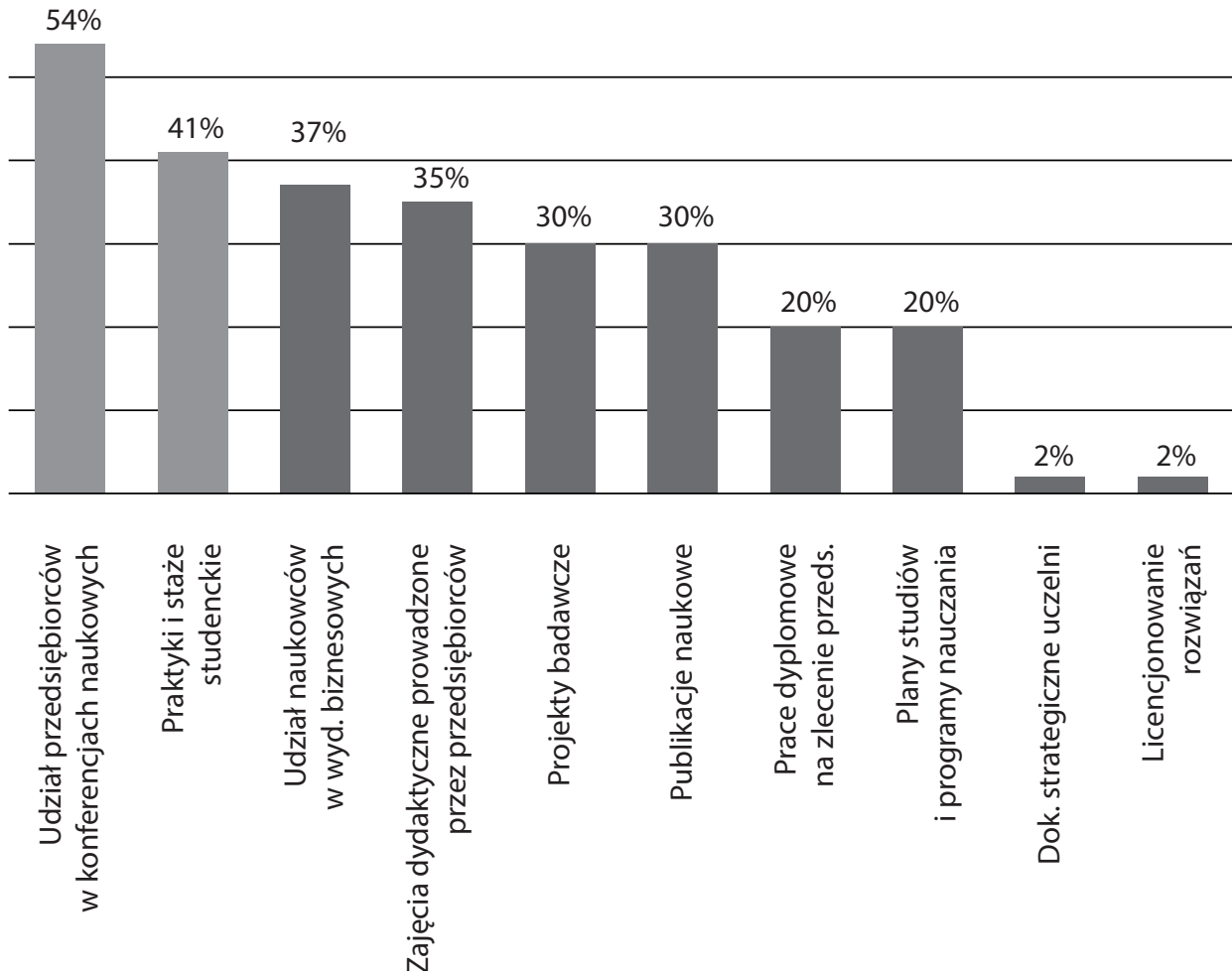

Rysunek 1. Wielokrotne podejmowanie działań w ramach współpracy z przedsiębiorstwami w poszczególnych obszarach

Źródło: opracowanie własne na podstawie przeprowadzonych badań.

Znikomy odsetek respondentów wskazał współpracę na rzecz długoterminowego rozwoju uczelni jako obszar częstej współpracy z przedsiębiorstwami, a jedynie co piąty zadeklarował opracowywanie kierunków studiów wraz $\mathrm{z}$ firmami.

Można wysnuć wniosek, iż najczęściej podejmowana jest współpraca w obszarach organizacyjnych, przy realizowaniu bieżących zadań, takich jak organizowanie konferencji czy przeprowadzenie zajęć dydaktycznych. Natomiast brakuje wyraźnej współpracy ze stroną biznesową przy ustalaniu strategii wydziałów czy wyznaczaniu długoterminowych celów.

Dla zdecydowanej większości obszarów współpraca nie jest podejmowana w charakterze stałym. Jedynie 7\% respondentów wskazało stałą współpracę przy następujących aktywnościach:

- udoskonalanie produktu/usługi;

- innowacje techniczne i technologiczne;

- zaangażowanie praktyków w realizowanie zajęć dydaktycznych. 
Na pytanie o dokonywanie oceny podejmowanej współpracy z przedsiębiorstwami aż $68,5 \%$ ankietowanych uznało, że takiej oceny nie przeprowadzają, a jedynie $15 \%$ stwierdziło, że dokonywana ocena ma charakter formalny.

Zebrany materiał badawczy pozwolił na stwierdzenie, że badane uczelnie podejmują współpracę z przedsiębiorstwami, lecz często jest ona prowadzona jednorazowo i bez stosowania sformalizowanych sposobów jej oceny. Uczelnie te nie dokonują analizy podjętej współpracy i nie gromadzą wiedzy dotyczącej relacji z poszczególnymi podmiotami biznesowymi. Wskutek tego nie ma formalnej informacji zwrotnej, która mogłaby stanowić podstawę do wymiany poglądów i dalszego rozwoju oraz doskonalenia relacji ocenianych jako potrzebne danej szkole wyższej.

\section{Wnioski końcowe i rekomendacje w zakresie rozwoju relacji uczelni publicznych z przedsiębiorstwami}

Przeprowadzone badania wykazały, że analizowane uczelnie nie dokonują formalnej oceny swojej współpracy z przedsiębiorstwami w aspekcie generowania oficjalnej informacji zwrotnej, na podstawie której można rozwijać i doskonalić najbardziej wartościowe dla uczelni relacje z przedstawicielami sfery biznesowej.

Wyniki przeprowadzonych badań pokazują niewykorzystany potencjał relacji wydziałów z przedsiębiorstwami, gdyż - pomimo istnienia kontaktów z przedstawicielami biznesu - prowadzone do tej pory działania nie wykorzystują wszystkich szans na pełną wymianę korzyści, zarówno ekonomicznych, jak i pozaekonomicznych ${ }^{24}$.

Analiza udzielonych odpowiedzi wskazuje, że prowadzona przez uczelnie współpraca najczęściej odnosi się do obszarów niezwiązanych ze strategicznym rozwojem wydziałów i odbywa się jedynie dorywczo, gdy nadarzy się ku temu okazja i pojawi się szansa na wspólne działanie. Bez wyznaczania celów strategicznych w obszarze współpracy, a więc świadomego budowania i umacniania relacji z przedsiębiorstwami, niemożliwe będzie planowanie działań długoterminowych,

24 W odniesieniu do teorii wymiany społecznej autorstwa Homansa, która jasno wskazuje, że ludzie wchodzą w interakcje z innymi, kierując się zasadą „coś za coś”, koszt i wartość tego, co dają i co otrzymują, zmienia się wraz z ilością tego, co dają i dostają. Czasem może wystąpić sytuacja, kiedy jedna strona otrzymuje korzyści ekonomiczne, a druga korzyści społeczne. Homans podkreśla również, że w miarę rozwoju relacji mogą pojawić się takie wartości jak zaufanie, zaangażowanie i pełna współpraca. 
przynoszących korzyści nie tylko samej uczelni, ale i przedsiębiorcom oraz całemu regionowi.

Autorka rozdziału przygotowała propozycję działań dotyczących planowania współpracy przez szkoły wyższe. Rysunek 2 przedstawia sekwencję działań, które powinny być podejmowane, aby uczelnie świadomie budowały i wzmacniały relacje z tymi podmiotami, które przyczynią się do ich rozwoju.

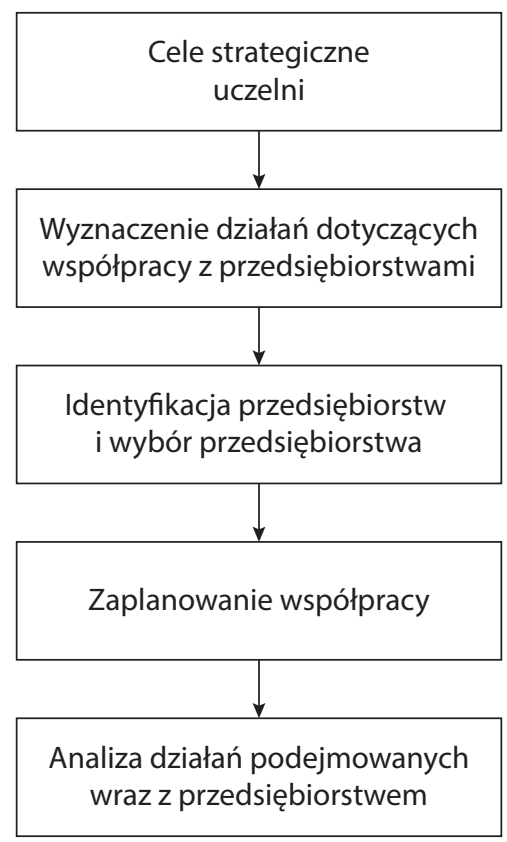

Rysunek 2. Zarządzanie relacjami uczelni z przedsiębiorstwami Źródto: opracowanie własne.

Podejmowanie powyższych działań pozwoli uczelni świadomie kierować całym procesem nawiązywania współpracy, a następnie jej rozwoju w kierunku trwałych relacji, które z perspektywy szkoły są najbardziej wartościowe. Zaproponowana sekwencja działań dotyczy zarządzania relacjami w aspektach:

- planowania obszarów współpracy, wynikających z celów strategicznych uczelni (analiza strategicznych celów wydziału i działań w kontekście współpracy z przedsiębiorstwami);

- identyfikacji pośród interesariuszy uczelni tych przedsiębiorstw, które mają największy wpływ na jej rozwój (ocena przedsiębiorstw w kontekście korzyści ze współpracy z nimi i potencjalnego generowania określonych wartości dla uczelni);

- wyboru przedsiębiorstwa, z którym możliwe będzie osiągnięcie celu; 
- planowania współpracy (sformułowanie propozycji potencjalnej korzyści dla przedsiębiorstwa, wynikającej ze współpracy z uczelnią);

- analizy podejmowanych działań (wspólna ocena planowanych działań oraz wzajemnych zobowiązań).

Po dokonaniu powyższych ocen na każdym z etapów osoba odpowiedzialna za prowadzenie współpracy po stronie uczelni powinna przeanalizować działania i wygenerować odpowiednią informację zwrotną dla kadry zarządzającej uczelnią, tak aby dokonać analizy faktograficznej poszczególnych etapów budowy relacji w ramach realizacji tematyki współpracy.

\section{Zakończenie}

Fundamentem podjętych w pracy badawczej rozważań jest założenie, że planowanie i świadomy rozwój współpracy przyczyniają się do budowania partnerskich relacji z przedsiębiorstwami, dając możliwość osiągnięcia jak największych wartości dla uczelni - zarówno w aspekcie ekonomicznym (na przykład w odniesieniu do korzyści finansowych), jak i pozaekonomicznym.

Zarządzanie relacjami jest procesem długotrwałym, angażującym wiele osób i podmiotów oraz wymagającym strategicznego myślenia i wspólnego kreowania warunków, w jakich wzrastają nowe pomysły i idee. Duże wyzwanie w tym procesie stanowi stałe monitorowanie potrzeb otoczenia społeczno-gospodarczego, w tym przedsiębiorstw.

Zastosowanie proponowanej przez autorkę rozdziału ścieżki działań do budowania relacji z przedsiębiorstwami pozwoli zarówno na realizację celów strategicznych wydziałów, jak i na spełnienie potrzeb oraz oczekiwań najważniejszych interesariuszy uczelni. Stawianie jasnych celów współpracy i wyznaczanie konkretnych działań, a następnie dokonywanie oceny poszczególnych etapów współpracy pozwoli na świadome budowanie relacji z przedsiębiorstwami, które stanowią grupę interesariuszy o dużej sile wpływu na rozwój szkoły wyższej, jednocześnie będąc partnerami przy realizacji określonych zadań. Dobre relacje buduje satysfakcja ze wspólnie zrealizowanego celu, a więc tworzy je pewien pakiet wartości materialnych i niematerialnych, odczuwanych przez obu partnerów podjętej wspólnie pracy. 
Bibliografia

Bakonyi J., Kapitat intelektualny uczelni a jakość kształcenia, [w:] M. Jabłoński (red.), „Zarządzanie. Zeszyty Naukowe Wyższej Szkoły Humanitas", Oficyna Wydawnicza Humanitas, Sosnowiec 2009, s. 38-45.

Drapińska A., Zarzq̨dzanie relacjami na rynku usług edukacyjnych szkół wyższych, Wydawnictwo Naukowe PWN, Warszawa 2012.

Freeman R.E., Strategic Management. A stakeholder approach, Cambridge University Press, Cambridge 2010.

Geryk M., Spoteczna odpowiedzialność uczelni w percepcji jej interesariuszy. Raport z badań, Oficyna Wydawnicza SGH - Szkoła Główna Handlowa w Warszawie, Warszawa 2010.

Helgesen O., Marketing for Higher Education: A Relationship Marketing Approach, „, Journal of Marketing for Higher Education" 2008, vol. 18(1), s. 50-78.

Homans G.C., Social Behaviour as Exchange, „American Journal of Sociology” 1958, vol. 63, no. 6, s. 597-606.

Koj K., Relacje z otoczeniem gospodarczym jako element ksztattowania programu ksztatcenia. Doświadczenia z Programu Partnerstwa Biznesowego w Wydziale Zamiejscowym w Chorzowie WSB w Poznaniu, [w:] J. Dworak, J. Jaworski, Zarzq̨dzanie szkołq̨ wyższq̨: dylematy i wyzwania, t. 14, CeDeWu, Warszawa 2011, s. 81-95.

Ławicka M., Różnorodność oferty edukacyjnej publicznych uczelni w Polsce, „Przedsiębiorczość i Zarządzanie" 2017, t. XVIII, z. 11, cz. 2, s. 155-168.

Ławicki J., Marketing sukcesu - partnering, Wydawnictwo Difin, Warszawa 2005.

Misja, wizja i cele strategiczne szkolnictwa wyższego w Polsce w perspektywie 2020 roku, Ernst \&Young Business Advisory i Instytut Badań nad Gospodarką Rynkową, listopad 2009, https:// docplayer.pl/16287467-Misja-wizja-i-cele-strategiczne-szkolnictwa-wyzszego-w-polsce-w-perspektywie-2020-roku-listopad-2009.html (dostęp: 20.12.2019).

Pluta-Olearnik M., Przedsiębiorcza uczelnia i jej relacje z otoczeniem, Wydawnictwo Difin, Wrocław 2009.

Prahalad C.K., Ramaswamy V., Przyszłość konkurencji. Współtworzenie wyjq̨tkowej wartości wraz z klientem, Polskie Wydawnictwo Ekonomiczne, Warszawa 2005.

Rogoziński K., Zarzqdzanie relacjami w ustugach, Wydawnictwo Difin, Warszawa 2006.

Słownik języka polskiego PWN, www.sjp.pwn.pl (dostęp: 28.12.2019).

Ustawa z dnia 20 lipca 2018 r. - Prawo o szkolnictwie wyższym i nauce (Dz.U. z 2018 r., poz. 1668).

\section{Streszczenie}

Uczelnie nie wykorzystują wszystkich szans na pełną wymianę korzyści - zarówno materialnych, jak i niematerialnych - jakie mogłyby odnieść przy wspólnej realizacji projektów z przedsiębiorstwami. Celem przeprowadzonych na potrzeby opracowania badań była charakterystyka budowanych przez uczelnie relacji z przedsiębiorstwami w zakresie obszarów prowadzonej współpracy oraz analizy i wyciągania wniosków ze zrealizowanych projektów. W niniejszym opracowaniu jako podmiot rozważań i badań wybrano wydziały ekonomiczne publicznych uczelni w województwie zachodniopomorskim. Wykorzystano następujące metody badawcze: krytyczną analizę literatury przedmiotu oraz metodę sondażu diagnostycznego (kwestionariuszową). Rozdział przedstawia propozycję działań dotyczących zarządzania relacjami przez szkoły wyższe.

Słowa kluczowe: relacje, uczelnia, interesariusze, ocena współpracy 
Strategic management of relations of public universities with enterprises in Poland

\section{Abstract}

The purpose of the research was to characterize relations between universities and enterprises. In this study, as the subject of consideration and research, the economic faculties of public universities in the West Pomeranian Voivodeship were selected. The following research methods were used: critical analysis of the literature and diagnostic questionnaire method. The article presents a proposal of strategic relationship management of universities.

Keywords: relations, university, stakeholders, cooperation evaluation 